Rebouças et al (2014)

\title{
COMPARISON BETWEEN THE USE OF PANORAMIC RADIOGRAPHY AND CONE BEAM COMPUTED TOMOGRAPHY TO LOCATE DENTAL ELEMENTS SEVERE INTRUDED DUE TO TRAUMA: CASE REPORT
}

\section{Pedro Diniz Rebouças ${ }^{1}$, Lorena Walesca Macedo Rodrigues ${ }^{2}$, Adriana Kelly de Sousa Santiago ${ }^{3}$, Clarice Santana Milagres ${ }^{4}$, Juliana Oliveira Gondim ${ }^{5}$, José Jeová Siebra Moreira-Neto ${ }^{5}$}

${ }^{1}$ Dentista. Mestrando em Odontologia (Odontopediatria). Departamento de Odontologia Infantil, Faculdade de Odontologia de Piracicaba FOP/UNICAMP.

${ }^{2}$ Acadêmica do Curso de Odontologia da Univesidade Federal do Ceará.

${ }^{3}$ Dentista. Doutoranda em Clínica Odontológica (Odontopediatria). Departamento de Clínica Odontológica, Curso de Odontologia da Universidade Federal do Ceará.

${ }^{4}$ Enfermeira. Doutoranda em Odontologia (Saúde Coletiva), Departamento de Odontologia Social, Faculdade de Odontologia de Piracicaba FOP/UNICAMP.

${ }^{5}$ Dentista. Professor de Odontopediatria do Departamento de Clínica Odontológica, Curso de Odontologia da Universidade Federal do Ceará.

\begin{abstract}
Intrusive luxation is a kind of traumatic injury characterized by an axial displacement of the tooth toward the alveolar bone. Its main causes are bicycle accidents, sports/recreational activities, and falls or collisions. Treatment strategies include waiting for the tooth to return to its position, immediate surgical repositioning and repositioning through dental traction by orthodontic devices. The correct diagnosis must be based on clinical and radiographic exams and it is crucial for decision-making in the treatment of injured patients. Currently, the cone beam computed tomography (CBCT) has been widely used in orthodontics, restorative dentistry and implantology as well as in the diagnosis of complex dental trauma. This article reports a case of severe dental intrusion, in which the cone beam computed tomography (CBCT) was performed because of doubts generated after clinical examination and panoramic radiograph analyze. This case report confirmed that the CBCT is an important exam to correct diagnostic.
\end{abstract}

Keywords: Dental intrusion. Dental injury. Imaging exams.

\section{RESUMO}

Luxação intrusiva é um tipo de lesão traumática caracterizada por um deslocamento axial do dente para o osso alveolar. Suas principais causas são os acidentes de bicicleta, esportes/atividades recreativas, e quedas ou colisões. As estratégias de tratamento incluem a espera para o dente para retornar à sua posição, reposicionamento cirúrgico imediato e reposicionamento através de tração dental por aparelhos ortodônticos. O diagnóstico correto deve ser baseada em exames clínicos e radiográficos e é crucial para a tomada de decisão no tratamento de pacientes feridos. Atualmente, a tomografia computadorizada (CBCT) tem sido amplamente utilizada em ortodontia, odontologia restauradora e implantologia, bem como no diagnóstico de trauma dental complexo. Este artigo relata um caso de intrusão dental severa, em que a tomografia computadorizada (CBCT) foi realizada por causa de 
Rebouças et al (2014)

dúvidas geradas após exame clínico e radiografia panorâmica analisar. Este relato de caso confirmou que a CBCT é um exame importante para corrigir diagnóstico.

Palavras-chave: intrusão dental, lesão Dental, exames de imagem.

\section{INTRODUCTION}

Dental intrusion is the displacement of the tooth into the alveolar bone along the axis of the tooth and is accompanied by comminution or fracture of the alveolar socket $^{1}$.In prior studies, the traumatic intrusion of permanent teeth has been found to represent up to $0.5-7,2 \%$ of all traumas affecting permanent dentditions, being considered a rare ${ }^{1,2}$. The main causes of intrusive injuries in permanent teeth include bicycle accidents, sports and recreational activities, and falls or collisions ${ }^{3}$ and it is considered one of the most severe types of dental injuries to the teeth because it might cause great damage to the periodontal ligament (PDL), the pulp and the alveolar bone ${ }^{4}$.

The intrusive luxation has a poor prognosis, predominating severe consequences in long term ${ }^{1}$, including pulp necrosis, inflammatory radicular resorption, dento-alveolar ankylosis, loss of marginal bone support, pulp tissue calcification, paralysis or disturbance of radicular development and gingival retraction ${ }^{5}$. Acute management of an intruded tooth in the young permanent dentition is restricted to three treatment strategies: spontaneous re-eruption, orthodontic or surgical repositioning. The choice of treatment will depend on the degree of root development and intrusion, presence of alveolar fracture and multiple intrusion intrusion ${ }^{1,6,7}$.

To achieve a correct decision is essential to have a correct diagnosis, based on an accurate clinical examination based on clinical history and laboratory tests such as radiography. However, $\mathrm{x}$ rays have limitations because it presents a two-dimensional image of three- dimensional structures and some medical conditions can lead to diagnostic error. Recently, the routine use of computed tomography has favored the diagnosis of complex trauma.

Among the imaging exams, the cone beam computed tomography (CBCT) is the technological development of imaging studies, characterized by providing radiation doses significantly reduced and produce minimally distorted images of the craniofacial region ${ }^{8}$. The introduction of cone-beam computed tomography (CBCT) has provided a significantly improve in the methods for the diagnosis, treatment planning, and follow up of endodontic lesions, but its advantages should only be used carefully in unusually complex treatment situations ${ }^{9-11}$.

Currently, this technique has been widely used in the diagnosis of the position of impacted teeth, orthodontics, restorative dentistry and as a guide to oral and maxillofacial surgery and implatology ${ }^{12}$.

\section{CASE REPORT}

A 12-year-old boy was referred to our Pediatric Clinic of School of Dentistry at the Federal University of Ceará, 11 days after his trauma in 2013. The patient was hit by a car and taken by ambulance at the moment of the accident to a hospital to begin his treatment. He had your nose broken, the tooth 11 avulsed and reimplanted at the hospital and the tooth 21 severe intruded. When he first arrived in our clinic for the first exams, like anamnesis and radiographs of the injured teeth, he was with a wire composite splint of the tooth 11, so we splinted that tooth with stainless steel and a composite resin for adequate immobilization (Fig. 1). 


\section{Rebouças et al (2014)}

Figure 1 - Tooth 11 with stainless steel and a composite resin for adequate immobilization.

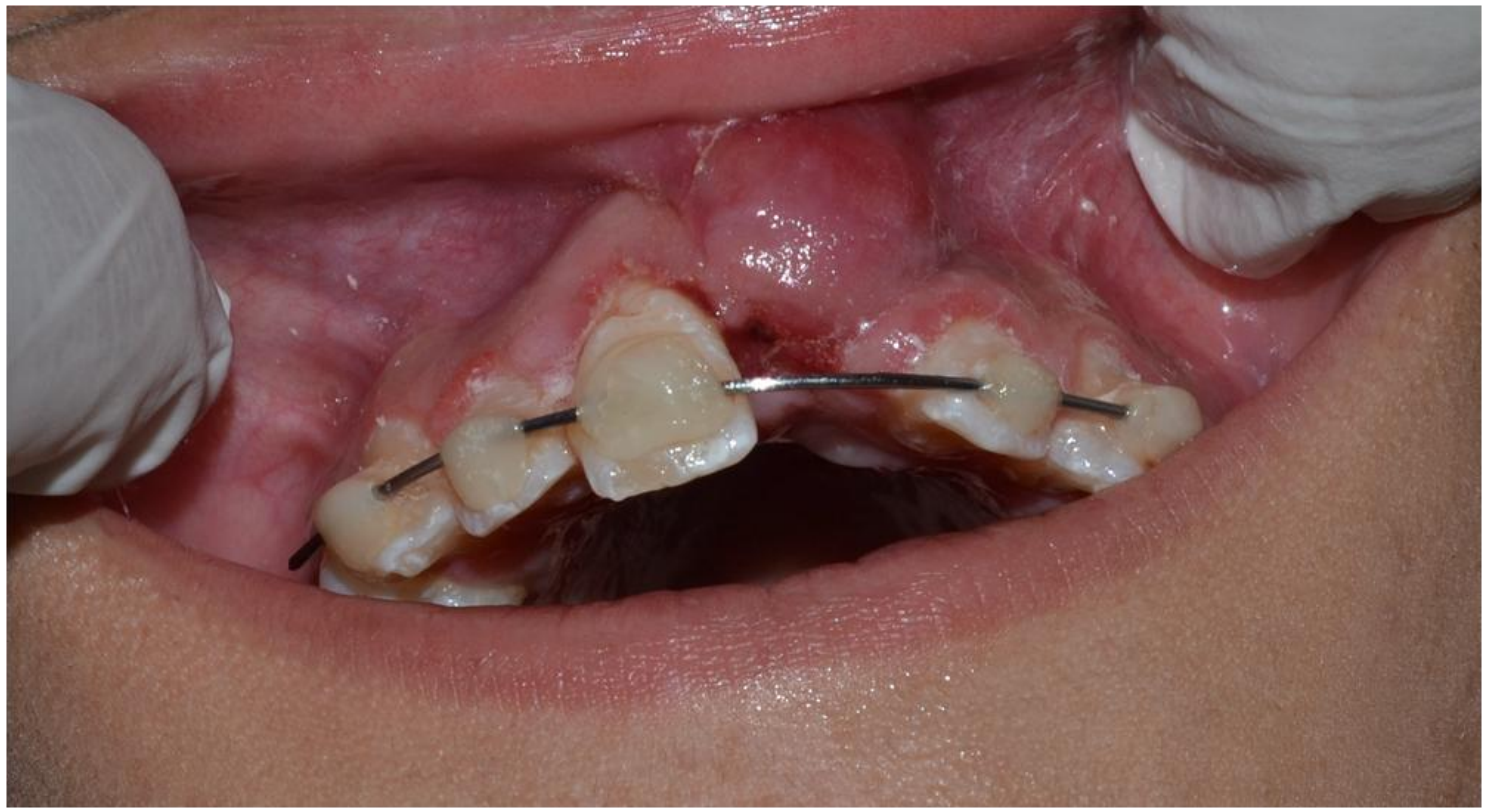

Clinically, we could not see the tooth 21 and the patient did not remember what happened to that tooth, then we radiographed and realized that the tooth 21 was injured by an intrusion (Fig.2). To

Figure 2 - Radiography of intruded tooth 21

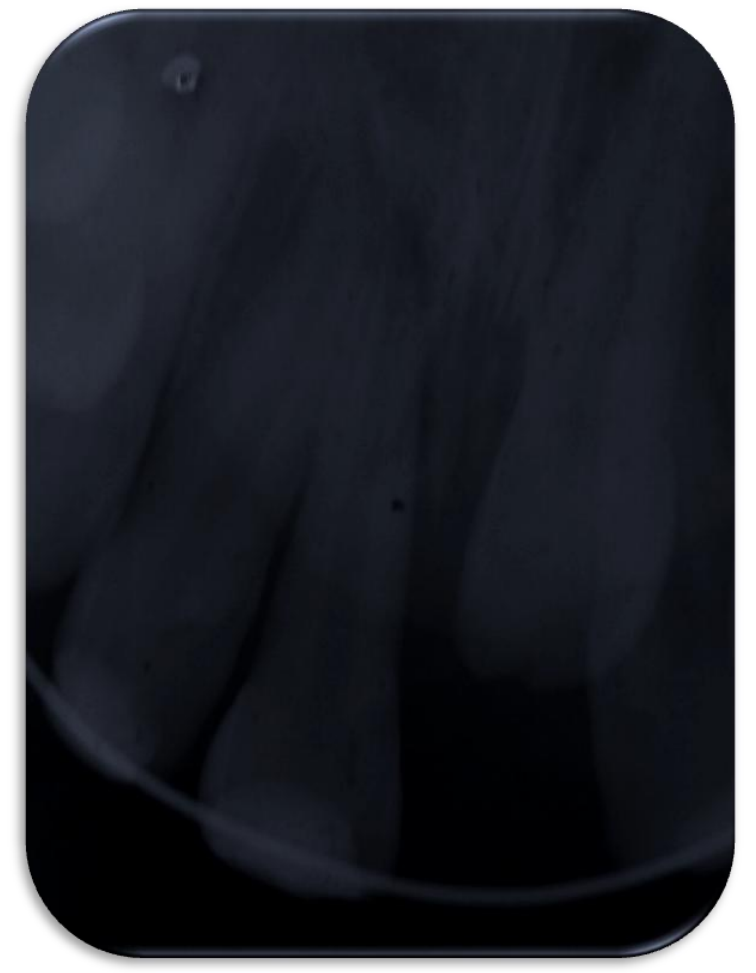




\section{Rebouças et al (2014)}

Figure 3 - Panoramic Radiography

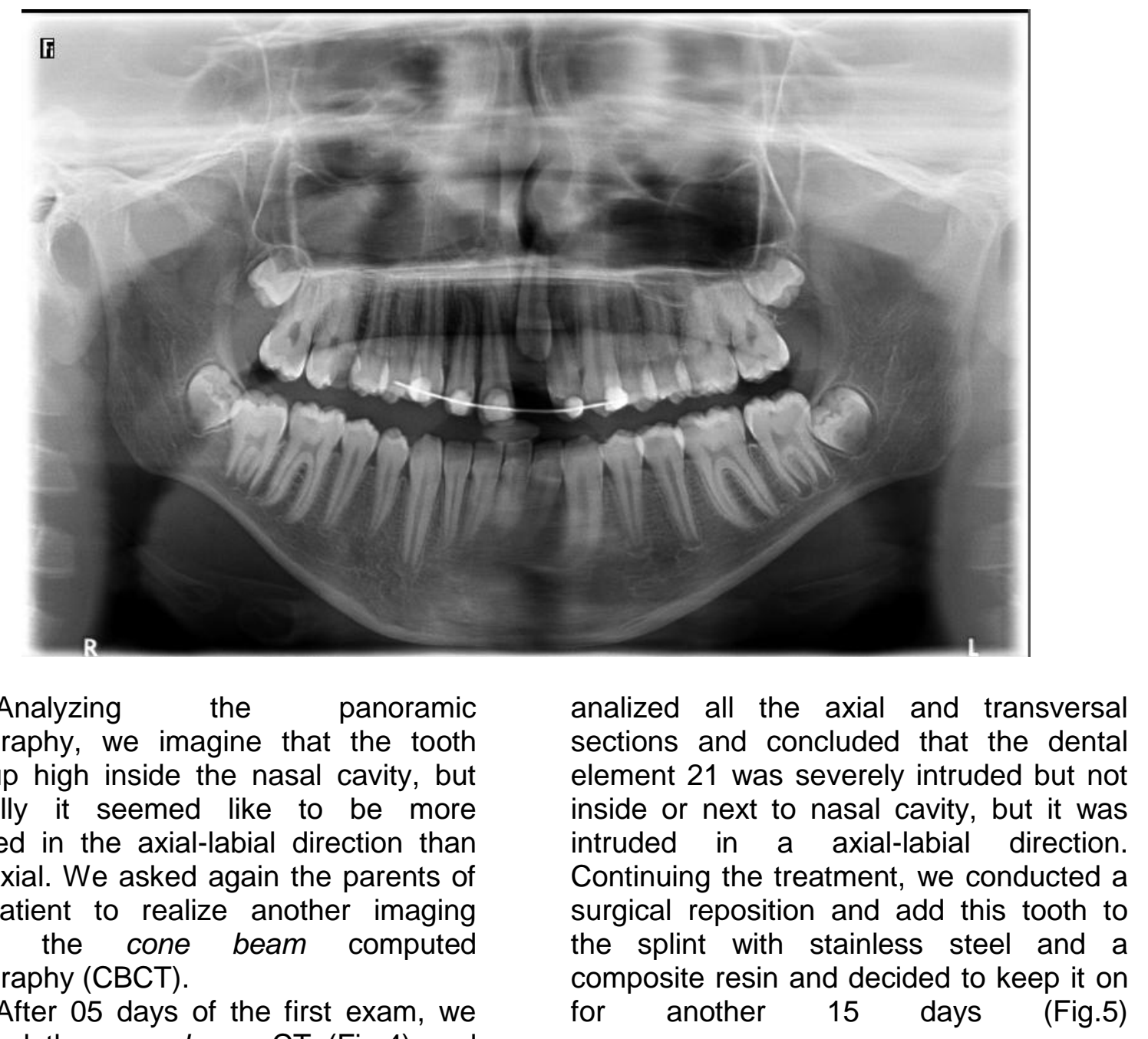

Figure 4 - Axial Cone beam computed tomography

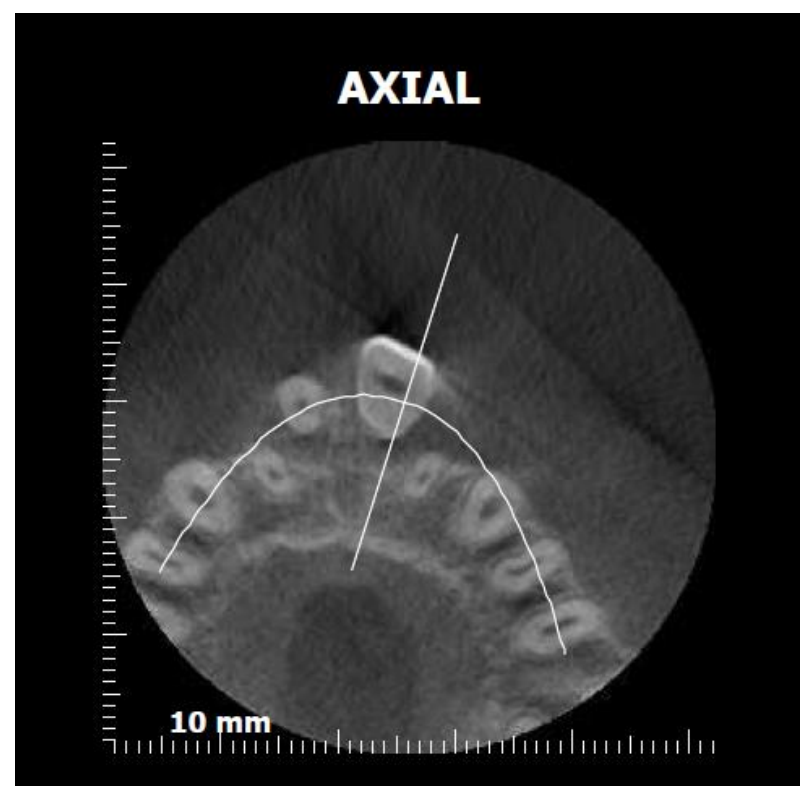

Revista da Faculdade de Ciências Gerenciais de Manhuaçu - FACIG (ISSN 1808-6136). Pensar Acadêmico, Manhuaçu, MG, v. 11, n. 2, p. 39-45, Agosto-Dezembro, 2014. 


\section{Rebouças et al (2014)}

Figure 5 - Tooth 21 with stainless steel and a composite resin for adequate immobilization after surgical reposition.

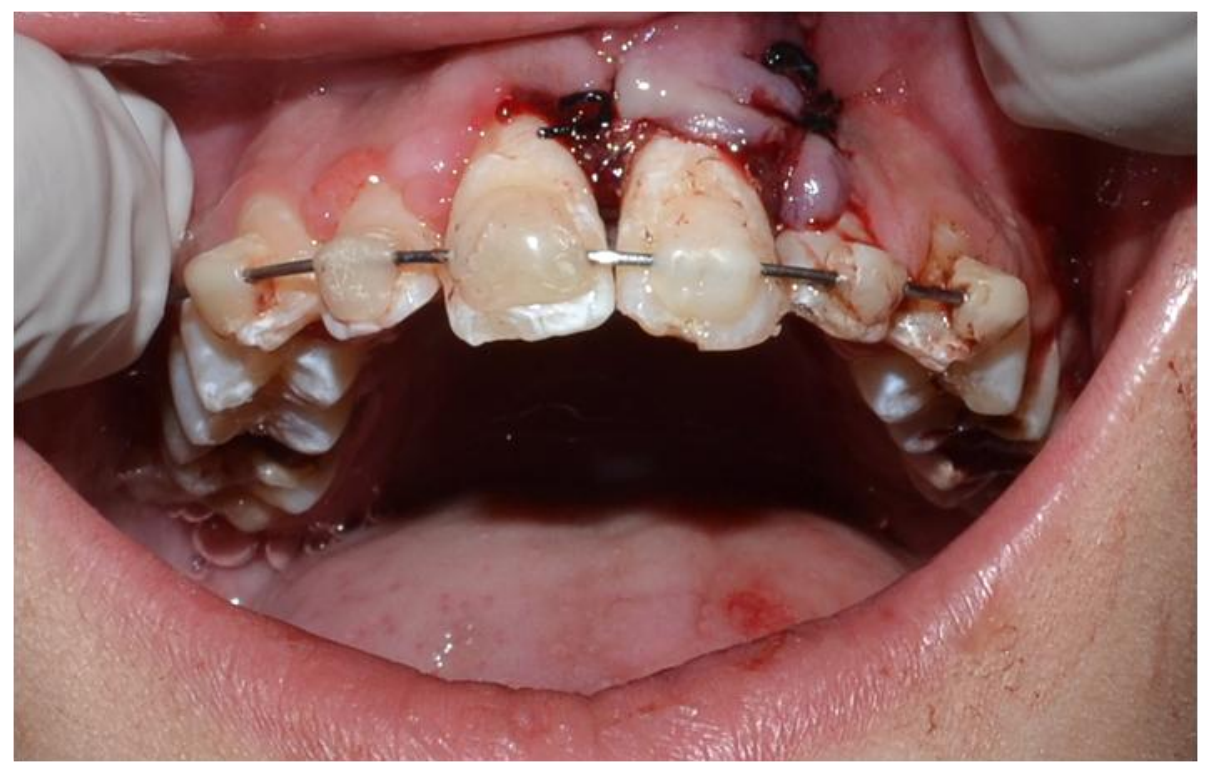

\section{DISCUSSION}

Usually, additional radiographic images are often required to ascertain the exact location of an intruded tooth ${ }^{12}$. The introduction of cone-beam computed tomography (CBCT) has provided a significantly improved method for the diagnosis, treatment planning, and cases follow up (RAFTER, 2005). The introduction of cone-beam computed tomography (CBCT) has provided a significantly improve in the methods for the diagnosis, treatment planning, and follow up of endodontic lesions, but its advantages should only be used carefully in unusually complex treatment situations ${ }^{9-}$ 12. That new imaging technich provides lowradiation, rapid image scanning with radiographic and $3 \mathrm{D}$ volumetric data for each patient ${ }^{13-15}$. Another imaging exam is the panoramic radiograph, which is used to aid in determining the vertical position and horizontal angulation ${ }^{16}$.

CBCT uses a cone-shaped radiation to gather information with high spatial resolution in the maxillofacial region ${ }^{17}$ doing a synchronized rotation with an area detector traveling $360 \mathrm{u}$ around the patient's head ${ }^{18}$. There is a wide variety amongst CBCT machines in terms of image quality and dose, with the latter ranging from an equivalent of 2 to 100 times a panoramic equivalent ${ }^{4}$.

Using an orthogonal projection of its beam, CBCT images are inherently more accurate than traditional x-rays. Instead of it, panoramic radiographs have an unusual projection error because the main path of the x-ray beam comes from a slightly negative angulation. Comparing the volumetric $3 \mathrm{D}$ method of $\mathrm{CBCT}$ and traditional $2 \mathrm{D}$ radiographs, we found differences between each method related to specific situations and it must account those artifacts when reading the images ${ }^{19}$.

The imaging exams must be solicited by the professional every time he has a doubt about the dental intrusion or the locate of the intruded element. In this case, clinically we could perceive an intraoral swelling located in the buccal anterior region of oral cavity. As a way to solve our questions about the locate of the intruded tooth, we asked the parents to realize two different types of radiograph exams. Panoramic radiograph was asked first and since it only cans present a 2D image, it does not showed us the proper locate of the intruded tooth. Only with the CBCT the 
real locate of the tooth and its relations with others oral and facial structures could be really noticed.

According to International Association of Dental Traumatology ${ }^{20}$, the treatment to teeth with complete root formation may vary depending on the severity of the intrusion. If the tooth intruded less than $3 \mathrm{~mm}$ the professional should allow the re-eruption without any intervention, but if any movement was not observed after 2-4 weeks or the tooth was intruded 4-7 $\mathrm{mm}$ the surgical or orthodontic reposition must be done before ankylosis develop. To teeth intruded beyond $7 \mathrm{~mm}$ only the surgical reposition should be done. After the reposition, the tooth has to be immobilized with a stainless steel and composite resin splint. That splint must be followed up by 2 weeks and removed after that time.

Analyzing only the panoramic radiograph, firstival we planned to do the surgical reposition with a different approach. Worried about the proximity of important structures, the first plan was realizing the access to the tooth by the nasal cavity. But, analyzing the CBCT, it was not necessary, because, as said before, the tooth was intruded only in an axial-labial direction.

The case described in this study confirmed that the CBCT is an important exam to correct diagnostic. However the clinician does not always have access to this type of technology to conduct a clinical evaluation and appropriate clinical history for a correct decision being necessary.

\section{REFERENCES}

1. ANDREASEN J.O., BAKLAND L.K., ANDREASEN F.M. Traumatic intrusion of permanent teeth. Part 2. A clinical study of the effect of preinjury and injury factors, such as sex, age, stage of root development, tooth location, and extent of injury including number of intruded teeth on 140 intruded permanent teeth. Dent Traumatol 2006;22:90-8.

2. SOUSA D.L. et al. Prevalência de trauma dental em crianças atendidas na Universidade Federal do Ceará. Rev. odonto ciênc. 2008;23(4):355-359.

3. TRAEBERT J. et al. Prevalence of traumatic dental injury and associated factors among 12-yearold school children in Florianopolis, Brazil. Dent Traumatol 2003;19:15-8.

4. TSILINGARIDIS G. et al. Intrusive luxation of 60 permanent incisors: a retrospective study of treatment and outcome.

Dental Traumatology 2012; 28: 416-422.

5. ANDREASEN J.O., ANDREASEN FM. Intrusive luxation. In: Andreasen $\mathrm{JO}$, Andreasen $\mathrm{FM}$, Andersson L, editors. Textbook and color atlas of traumatic injuries to the teeth, 4th edn. Oxford, UK: Wiley-Blackwell; 2007. p. 428-43.

6. CHAUSHU S. et al. Patients' perceptions of recovery after surgical exposure of impacted maxillary teeth treated with an open-eruption surgical-orthodontic technique. Eur J Orthod 2004;26:591-6.

7. ANDREASEN J.O., BAKLAND L.K., ANDREASEN F.M. Traumatic intrusion of permanent teeth. Part 3. A clinical study of the effect of treatment variables such as treatment delay, method of repositioning, type of splint, length of splinting and antibiotics on 140 teeth. Dent

Traumatol 2006;22:99-111.

8. SCARFE W.C., FARMAN A.G., SUKOVIC P. Clinical applications of cone-beam computed tomography in dental practice. $\mathbf{J}$ Can Dent Assoc, Ottawa 2006;72:75-80.

9. EUROPEAN COMMISSION. Cone Beam $C Y$ for dental and maxillofacial radiology. evidence based guidelines. Luxembourg, Europe: European Commission; 2012. Radiation Protection $\mathrm{N}^{\circ}$ 1720.

10. PAUWELS R. et al. SEDENTEXCT Project Consortium; Effective dose 
range for dental cone beam computed tomography scanners. Eur J Radiol 2012;81:267-71.

11. PAUWELS R. et al. SEDENTEXCT Project Consortium; Comparison of spatial and contrast resolution for cone-beam computed tomography scanners. Oral Surg Oral Med Oral Pathol Oral Radiol 2012;114:127-35.

12. LANGLAND O.E., SIPPY F.H. Anatomic structures as visualized on the orthopantomogram. Oral Surg Oral Med Oral Pathol 1968;26: 475-84.

13. RAFTER M. Apexification: a review. Dent Traumatol 2005;21:1-8. 17

14. ANDREASEN J.O. et al. Traumatic intrusion of permanent teeth. Part 1. An epidemiological study of 216 intruded permanent teeth. Dent Traumatol 2006;22:83-9.

15. CHALA S., ABOUQAL R., RIDA S. Apexification of immature teeth with calcium hydroxide or mineral trioxide aggregate: systematic review and meta-analysis. Oral Surg Oral Med Oral Pathol Oral Radiol Endod 2011;112:e36-42.

16. GANDOLFI M.G. et al. New tetrasilicate cements as retrograde filling material: an in vitro study on fluid penetration. J Endod 2007;33:742-5

17. CHAUSHU S. et al. Emergency orthodontic treatment after the traumatic intrusive luxation of maxillary incisors. Am $\mathbf{J}$ Orthod Dentofacial 2004;126:162-72.

18. NOAR J.H, PABARI S. Cone beam computed tomography - current understanding and evidence for its orthodontic applications? J of Orthod 2013; 40:5-13

19. HANEY E. et al. Comparative analysis of traditional radiographs and cone-beam computed tomography volumetric images in the diagnosis and treatment planning of maxillary impacted canines. Am J Orthods
Dentofacial Orthop 2010; 137: 591-597.

20. ANDERSSON et al., International Association of Dental Traumatology guidelines for the management of traumatic dental injuries: 2. Avulsion of permanent teeth. Dental Traumatology 2012; 28: 88-96. 